Check for updates

Cite this: RSC Adv., 2019, 9, 20603

Received 15th March 2019

Accepted 5th June 2019

DOI: $10.1039 / c 9 r a 01986 c$

rsc.li/rsc-advances

\title{
Effects of the combined pollution of cadmium, lead and zinc on the phytoextraction efficiency of ryegrass (Lolium perenne L.)
}

\author{
Jun Zhang, ${ }^{\text {ab }}$ Ningning Yang, ${ }^{a}$ Yani Geng, (D) *a Jinhong Zhou and Ji Lei ${ }^{a}$
}

The effects of cadmium ( $\mathrm{Cd}$ ), lead (Pb) and zinc ( $\mathrm{Zn})$ combined pollution on the phytoextraction efficiency of ryegrass (Lolium Perenne L.) were investigated in this work. Orthogonal experimental design was adopted in pot test (composition and interaction). The results showed that, with the increase of heavy metal concentration, the accumulation of elements in ryegrass was increased. The order of enrichment in root was $\mathrm{Cd}>\mathrm{Pb}>\mathrm{Zn}$, was $\mathrm{Zn}>\mathrm{Pb}>\mathrm{Cd}$ in the stem and leaf, and the order of total $\mathrm{EF}$ was $\mathrm{Cd}>\mathrm{Zn}>\mathrm{Pb}$. Ryegrass revealed the strongest enrichment effect on soil $\mathrm{Cd}$ and a strong ability to transfer $\mathrm{Zn}$. Besides, ryegrass showed good potential in phytoextraction heavy metal $\mathrm{Cd}$ pollution and $\mathrm{Cd} \times \mathrm{Zn}$ combined pollution.

\section{Introduction}

Soil heavy metal pollution is often not caused by a single element pollutant, but by a variety of heavy metal (such as cadmium, lead, zinc, copper, and arsenic) $)^{\mathbf{1}, 2}$ pollutants and their interaction; ${ }^{3}$ studies have shown that the mechanism of action of combined pollution is extremely complex and usually related to the species and concentration of heavy metals. ${ }^{\mathbf{4}, 5}$ Moreover, the interaction between heavy metals has been manifested as synergistic, additive or antagonistic. ${ }^{6-8}$ At present, studies on the soil chemistry and phytoremediation of heavy metals mainly focus on a single heavy metal, and only few studies have been conducted on the effect of the interaction of multiple heavy metal complexes on the phytoremediation efficiency; ${ }^{9,10}$ thus, it is important to study the effect of soil heavy metal combined pollution on the phytoremediation efficiency of plants to further understand the interaction between different heavy metals in the soil.

Considering the heavy metal complex pollution, the current study mainly focuses on the accumulation, enrichment, phytoextraction and interaction mechanism of heavy metals in plants. Studies have shown that the effect of heavy metal combined pollution on phytoremediation is related to the characteristics of heavy metals, ${ }^{\mathbf{1 1}, 12}$ plant factors and environmental factors. $^{13,14}$ The main mechanism of interaction of combined heavy metal pollution are listed below, compete the adsorption point, activate the complex protease, ${ }^{\mathbf{1 5 , 1 6}}$ interfere with the

${ }^{a}$ Shaanxi Key Laboratory of Disaster Monitoring and Mechanism Simulation, College of Geography and Environment, Baoji University of Arts and Sciences, Baoji 721013, P. R. China.E-mail: zhangjun1190@126.com; gyn1977@126.com

${ }^{b}$ Key Laboratory of Subsurface Hydrology and Ecological Effect in Arid Region of Ministry of Education, Chang'an University, Xi'an 710054, China normal physiological and biochemical functions of plants, change cell structure and function, chelation or coprecipitation, ${ }^{17,18}$ interferes with the structural and functional absorption of plant biological macromolecules. ${ }^{19-22}$ Based on the abovementioned studies, significant progress has been made in the phytoremediation of soil heavy metal combined pollution; however, heavy metal combined pollution is not a simple addition of pollutions caused by single elements, and its effect on the phytoextraction efficiency is related to not only physical and chemical properties, species, concentration and proportion of heavy metals, but also the species and location of the plant and method and time. ${ }^{23,24}$

Ryegrass (Lolium perenne L.) is a fast growing, high biomass and drought-resistant forage grass widely grown in northern China. ${ }^{25-27}$ According to the literature, ryegrass shows a certain absorption capacity for cadmium, lead and zinc in soil and is a potential heavy metal-enriched plant. ${ }^{12}$ The species, ${ }^{28}$ growth status, ${ }^{20,29}$ enrichment site, ${ }^{30}$ physiological and biochemical characteristics $^{\mathbf{3 1}}$ and other factors of ryegrass show significant effects on the distribution of different heavy metals in soil-plant tissues $^{32-34}$ as well as the absorption, accumulation and enrichment capacity of various heavy metals at different sites. Since ryegrass is a potential heavy metal-enriched plant, it is necessary to improve and regulate its phytoextraction ability under heavy metal combined pollution.

An orthogonal experiment is a scientific and effective method to design experiments by the mathematical statistics theory and the orthogonality principle to simplify experiments and obtain data. ${ }^{35-37}$ Due to the complexity and interactivity of the effects of the combined pollution of different heavy metals on the efficiency of ryegrass restoration, an orthogonal experimental design was adopted in this study. It not only retains the advantages of the traditional single or combined experimental 
Table 1 Physical and chemical properties of the tested soil

\begin{tabular}{llllllll}
\hline & & & & & & \multicolumn{2}{c}{ Background values/mg kg $^{-1}$} \\
Indicators & $\mathrm{TN} / \mathrm{g} \mathrm{kg}^{-1}$ & $\mathrm{TP} / \mathrm{g} \mathrm{kg}^{-1}$ & $\mathrm{OM} / \%$ & $\mathrm{pH}$ & $\begin{array}{l}\mathrm{CEC} / \mathrm{cmol} \\
\mathrm{kg}^{-1}\end{array}$ & $\mathrm{Cd}$ & $\mathrm{Pb}$ \\
\hline Values & 1.78 & 2.53 & 3.1 & 8.3 & 8.9 & 0.62 & 12.2
\end{tabular}

Table 2 Orthogonal experimental design

\begin{tabular}{|c|c|c|c|c|c|c|c|}
\hline \multirow{2}{*}{$\begin{array}{l}\text { Treatment } \\
\text { levels }\end{array}$} & \multicolumn{3}{|c|}{$\underline{\mathrm{L}}_{16}\left(4^{5}\right) / \mathrm{mg} \mathrm{kg}^{-1}$} & \multirow{2}{*}{$\begin{array}{l}\text { Treatment } \\
\text { levels }\end{array}$} & \multicolumn{3}{|c|}{$\mathrm{L}_{8}\left(2^{7}\right) / \mathrm{mg} \mathrm{kg}^{-1}$} \\
\hline & $\mathrm{Cd}$ & $\mathrm{Pb}$ & $\mathrm{Zn}$ & & $\mathrm{Cd}$ & $\mathrm{Pb}$ & $\mathrm{Zn}$ \\
\hline Level 1 & 0 & 0 & 0 & Level 1 & 20 & 300 & 250 \\
\hline Level 2 & 10 & 100 & 150 & Level 2 & 40 & 700 & 450 \\
\hline Level 3 & 30 & 500 & 350 & & & & \\
\hline Level 4 & 50 & 900 & 550 & & & & \\
\hline
\end{tabular}

design method, but also represents the effect of the interaction between combined and interactive pollution on the investigation target.

In this study, the heavy metals cadmium, lead and zinc, which had caused serious pollution in Shaanxi province, were selected as the sources of pollution. Ryegrass was taken as the pot experiment object, and combined and interactive orthogonal experimental methods were adopted to study the effects of different types and concentrations of heavy metals on the phytoextraction efficiency of ryegrass. Thus, this study can provide a theoretical and practical basis for understanding the effect of soil heavy metal combined pollution on the heavy metal phytoremediation mechanism of ryegrass.

\section{Materials and methods}

\subsection{Test soil and plant}

The tested soil was obtained from the loess of Sickle Bay area in North Shaanxi. After the collected soil samples are naturally air- dried, plant residues, stones and other debris are picked out, ground and then screened by $2 \mathrm{~mm}$ sieve. $\mathrm{CO}\left(\mathrm{NH}_{2}\right)_{2}(400 \mathrm{mg}$ $\left.\mathrm{kg}^{-1}\right), \mathrm{KH}_{2} \mathrm{PO}_{4}\left(200 \mathrm{mg} \mathrm{kg}^{-1}\right)$ and $\mathrm{K}_{2} \mathrm{SO}_{4}\left(300 \mathrm{mg} \mathrm{kg}^{-1}\right)$ were mixed thoroughly with the soil sample as the basal fertilizer. Moreover, $\mathrm{Cd}, \mathrm{Zn}$ and $\mathrm{Pb}$ were added to the soil in the form of $\mathrm{CdCl}_{2} \cdot 2.5 \mathrm{H}_{2} \mathrm{O}, \mathrm{Zn}\left(\mathrm{NO}_{3}\right)_{2} \cdot 6 \mathrm{H}_{2} \mathrm{O}$ and $\mathrm{Pb}\left(\mathrm{NO}_{3}\right)_{2}$ aqueous solutions, which were fully stirred and preserved. The concentrations of three kinds of heavy metals were in accordance with the Chinese soil environmental quality standard (GB 15618-2008).

The total nitrogen (TN, salicylic acid method), total phosphorus (TP, sulfuric acid-perchloric acid heating digestion method), and organic matter content (OM, potassium dichromate method), $\mathrm{pH}$ value (potentiometry), cation exchange capacity (CEC, EDTA-ammonium salt method) and background values of the three metal ions in the tested soil were determined and are listed in Table 1.

The tested plant was ryegrass, and the experiment was carried out between July 2017 and August 2017. The full-grain ryegrass seeds were selected, rinsed with deionized water and soaked for 24 hours before potting. The number of seeds was limited to about 30 . The pot was placed in a place that had uniform illumination and ventilation, and the moisture content in the soil was maintained at $60 \%$. After a week, the seeds in the pot sprouted; when the growth was stable, the plant and soil samples were obtained on the $42^{\text {nd }}$ day for investigation.

The plant roots, root soils and plant leaves were dried, cut into $0.1 \mathrm{~g}$ samples and placed in a microwave digestion tank for

Table 3 Accumulation of heavy metal elements in ryegrass in the combined orthogonal experiment

\begin{tabular}{|c|c|c|c|c|c|c|c|c|c|}
\hline \multirow[b]{2}{*}{ Treatments } & \multicolumn{3}{|c|}{$\begin{array}{l}\text { Heavy metal } \\
\text { elements }\end{array}$} & \multicolumn{3}{|c|}{ Heavy metal content in root $/ \mathrm{mg} \mathrm{kg}^{-1}$} & \multicolumn{3}{|c|}{ Heavy metal content in stem and leaf $/ \mathrm{mg} \mathrm{kg}^{-1}$} \\
\hline & $\mathrm{Cd}$ & $\mathrm{Pb}$ & $\mathrm{Zn}$ & $\mathrm{Cd}$ & $\mathrm{Pb}$ & $\mathrm{Zn}$ & $\mathrm{Cd}$ & $\mathrm{Pb}$ & $\mathrm{Zn}$ \\
\hline $\mathrm{T} 1$ & 1 & 1 & 1 & $0.84 \mathrm{k} \pm 0.01$ & $4.78 \mathrm{~g} \pm 0.08$ & $20.70 \mathrm{k} \pm 0.31$ & $0.04 \mathrm{~m} \pm 0.01$ & $4.78 \mathrm{~h} \pm 0.02$ & $3.41 \mathrm{n} \pm 0.05$ \\
\hline $\mathrm{T} 2$ & 1 & 2 & 2 & $0.14 \mathrm{~m} \pm 0.00$ & $32.56 \mathrm{~d} \pm 0.34$ & $41.94 \mathrm{~g} \pm 0.51$ & $0.02 \mathrm{~m} \pm 0.00$ & $1.68 \mathrm{k} \pm 0.02$ & $5.48 \mathrm{~m} \pm 0.11$ \\
\hline T3 & 1 & 3 & 3 & $0.14 \mathrm{~m} \pm 0.00$ & $27.36 \mathrm{de} \pm 0.33$ & $66.10 \mathrm{e} \pm 0.48$ & $0.02 \mathrm{~m} \pm 0.00$ & $20.98 \mathrm{~d} \pm 0.28$ & $29.09 \mathrm{~d} \pm 0.43$ \\
\hline T6 & 2 & 1 & 2 & $3.04 \mathrm{~g} \pm 0.02$ & $3.63 g \pm 0.01$ & $32.73 \mathrm{i} \pm 0.41$ & $0.26 \mathrm{k} \pm 0.00$ & $0.781 \pm 0.03$ & $7.951 \pm 0.08$ \\
\hline $\mathrm{T} 7$ & 2 & 4 & 3 & $1.63 \mathrm{j} \pm 0.01$ & $20.10 \mathrm{ef} \pm 0.22$ & $26.26 \mathrm{j} \pm 0.41$ & $0.66 \mathrm{i} \pm 0.01$ & $18.20 \mathrm{e} \pm 0.23$ & $17.63 \mathrm{i} \pm 0.52$ \\
\hline $\mathrm{T} 8$ & 2 & 3 & 4 & $2.23 \mathrm{i} \pm 0.02$ & $17.19 \mathrm{f} \pm 0.26$ & $64.97 \mathrm{e} \pm 1.11$ & $1.69 \mathrm{e} \pm 0.05$ & $16.90 \mathrm{f} \pm 0.43$ & $52.26 \mathrm{a} \pm 1.23$ \\
\hline $\mathrm{T} 9$ & 3 & 3 & 1 & $3.25 \mathrm{~g} \pm 0.29$ & $41.63 c \pm 0.17$ & $15.881 \pm 0.23$ & $1.95 \mathrm{~d} \pm 0.03$ & $22.98 \mathrm{a} \pm 0.33$ & $16.60 \mathrm{j} \pm 0.19$ \\
\hline $\mathrm{T} 10$ & 3 & 4 & 2 & $11.81 \mathrm{c} \pm 0.11$ & $30.49 \mathrm{~d} \pm 0.36$ & $32.41 \mathrm{i} \pm 0.52$ & $2.59 b \pm 0.04$ & $22.12 b \pm 0.26$ & $25.25 \mathrm{e} \pm 0.27$ \\
\hline $\mathrm{T} 11$ & 3 & 1 & 3 & $9.07 d \pm 0.10$ & $2.19 g \pm 0.04$ & $36.20 \mathrm{~h} \pm 0.82$ & $1.46 \mathrm{~g} \pm 0.01$ & $2.09 \mathrm{k} \pm 0.03$ & $42.45 b \pm 0.53$ \\
\hline $\mathrm{T} 16$ & 4 & 1 & 4 & $2.47 \mathrm{~h} \pm 0.17$ & $5.71 \mathrm{~g} \pm 0.04$ & $94.34 b \pm 2.59$ & $3.24 \mathrm{a} \pm 0.08$ & $1.95 \mathrm{k} \pm 0.05$ & $36.91 c \pm 0.38$ \\
\hline
\end{tabular}


digestion, and set constant volume. After passing the samples through a $0.45 \mu \mathrm{m}$ filter membrane, ICP-MS (NexION 350X, PE, USA) was used to determine the heavy metal content of the samples. In the experiment, the quality control was carried out using the Chinese national standard soil sample (gss-25) and plant standard sample (GB07603), and the element recovery rate was controlled between 92 and 105\%. Instrument quality control was performed using a standard solution (PE\#: N9303837) supplied by $\mathrm{PE}$ with the error range of $\pm 5 \%$. Each sample was measured three times, and the relative standard deviation (RSD) of each heavy metal element was less than $10 \%$. The reagents used in the experiment were of excellent grades.

\subsection{Orthogonal experiment design}

The orthogonal experiment design (OED) method is regarded as a modern approach to optimize and characterize experimental operation in many research areas. The orthogonal test method was adopted for test design and analysis in this study. It can reduce the number of tests, arrange the test methods scientifically and rationally and finally provide reliable test results. In this experiment, the number of heavy metal factors was $3(\mathrm{Cd}, \mathrm{Pb}$ and $\mathrm{Zn})$, and the level of each factor was 4 (different levels of concentration).

Bioconcentration factor (BCF), translocation factor (TF) and extraction efficiency (EF) were selected as indicators. Factors and levels were designed as shown in Table 2. The orthogonal experiment is described as $\mathrm{L}_{a}\left(b^{c}\right)$, where $\mathrm{L}$ stands for orthogonal design symbol, $a$ is the number of experimental designs, $b$ is the number of factor levels, and $c$ is the number of factors. The combined effect of $\mathrm{Cd}, \mathrm{Zn}$ and $\mathrm{Pd}$ on three phytoextraction indices was determined using the orthogonal table of 5 factors 4 level $\mathrm{L}_{16}\left(4^{5}\right)$. The 5 factors of the orthogonal table design could include 3 factors set in this experiment, the design level of the orthogonal table was 4 , the orthogonal design was 16 experiments, and each experiment was repeated three times, i.e., a total of 48 pot experiments were performed. After analyzing the leading influence of the combined orthogonal experiment, three factors, i.e. $\mathrm{Cd}, \mathrm{Pd}$ and $\mathrm{Zn}$, were selected to rearrange the orthogonal interaction table of $\mathrm{L}_{8}\left(2^{7}\right)$ to investigate the influence of the interactions of $\mathrm{Cd}, \mathrm{Pb}$ and $\mathrm{Zn}$ on the phytoextraction efficiency. The level of the interaction table design was 2 . The orthogonal design of interaction was 8 experiments, and each experiment was repeated three times, i.e., a total of 24 pot experiments were performed. A total of $48+24=72$ pot experiments were designed for the combined experiment and interactive experiment. The data obtained by the orthogonal experiment were analyzed by the SPSS software for variance (ANOVA) and significance of difference (Duncan, $P<0.05$ ).

\subsection{Phytoextraction efficiency evaluation factors}

The phytoextraction efficiency of ryegrass was evaluated by three factors, i.e., BCF, TF and EF, as shown in the formula (1)-(3): :

$$
\begin{aligned}
& \mathrm{BCF}=C_{\text {root }} / C_{\text {soil }} \\
& \mathrm{TF}=C_{\text {shoot }} / C_{\text {root }} \\
& \mathrm{EF}=C_{\text {shoot }} / C_{\text {soil }}
\end{aligned}
$$

where $C_{\text {root }}$ is the concentration of the heavy metal in the root, $\mathrm{mg} \mathrm{kg}^{-1}$. $C_{\text {soil }}$ is the concentration of the same heavy metal in the soil, $\mathrm{mg} \mathrm{kg}^{-1}$. $C_{\text {shoot }}$ is the concentration of heavy metal in the aerial part of the plant, $\mathrm{mg} \mathrm{kg}^{-1}$.
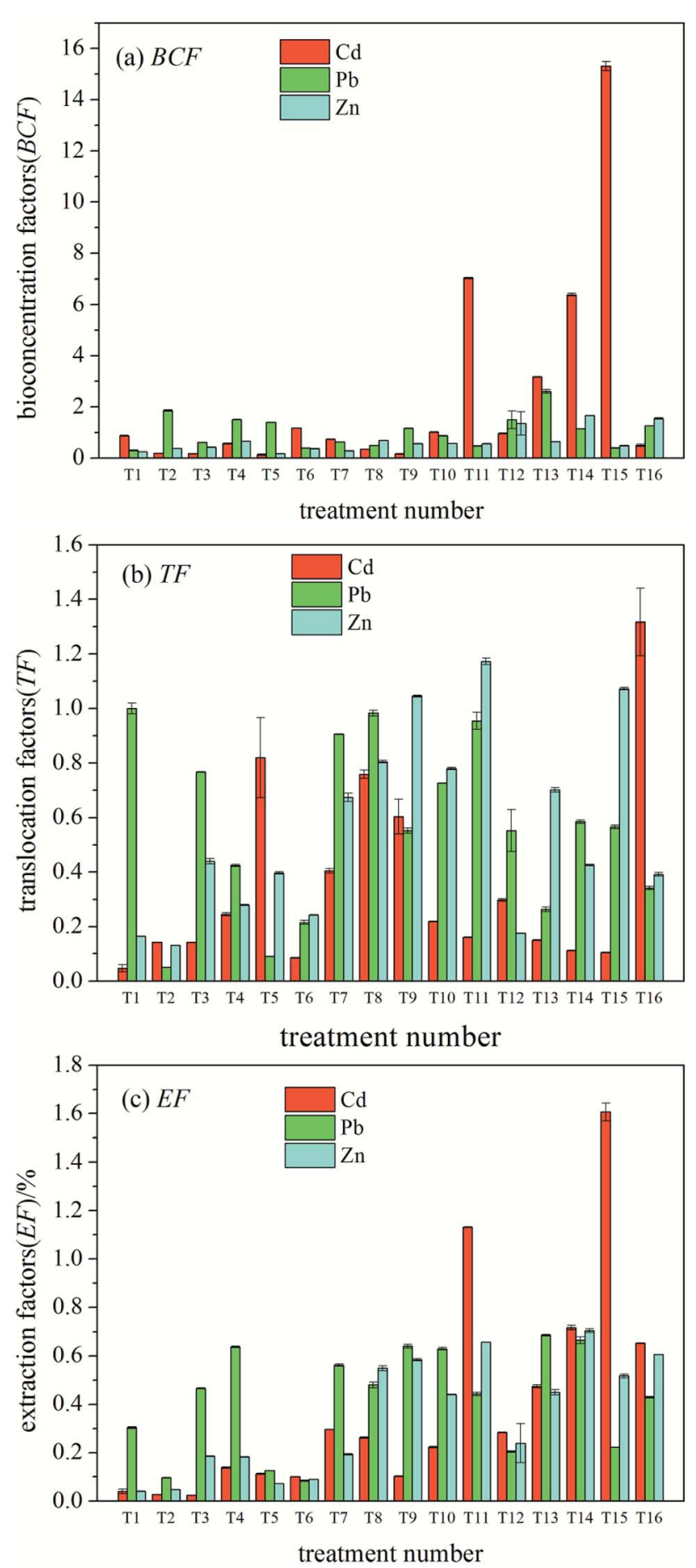

Fig. 1 Effects of the combined action of $\mathrm{Cd}, \mathrm{Pb}$ and $\mathrm{Zn}$ on the BCF, TF, and $E F$ of ryegrass. 
Table 4 Variance analysis of the orthogonal experiment of combined action (Cd)

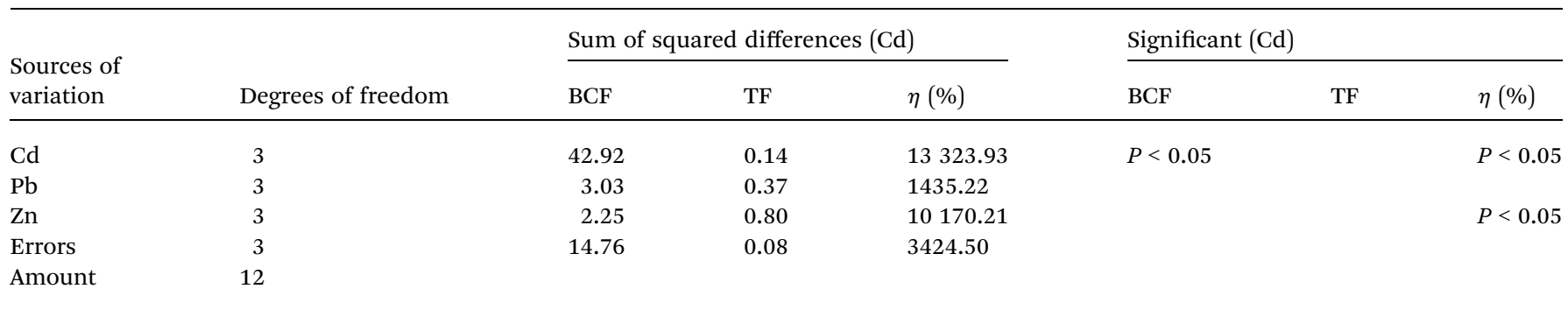

Table 5 Variance analysis of the orthogonal experiment of combined action (Pb)

\begin{tabular}{|c|c|c|c|c|c|c|c|}
\hline $\begin{array}{l}\text { Sources of } \\
\text { variation }\end{array}$ & Degrees of freedom & \multicolumn{3}{|c|}{ Sum of squared differences $(\mathrm{Pb})$} & \multicolumn{3}{|c|}{ Significant $(\mathrm{Pb})$} \\
\hline $\mathrm{Pb}$ & 3 & 1.34 & 0.61 & 6344.73 & & & $P<0.05$ \\
\hline $\mathrm{Zn}$ & 3 & 1.93 & 0.00 & 149.92 & & & \\
\hline Errors & 3 & 1.36 & 0.76 & 499.64 & & & \\
\hline
\end{tabular}

Table 6 Variance analysis of orthogonal experiment of combined action (Zn)

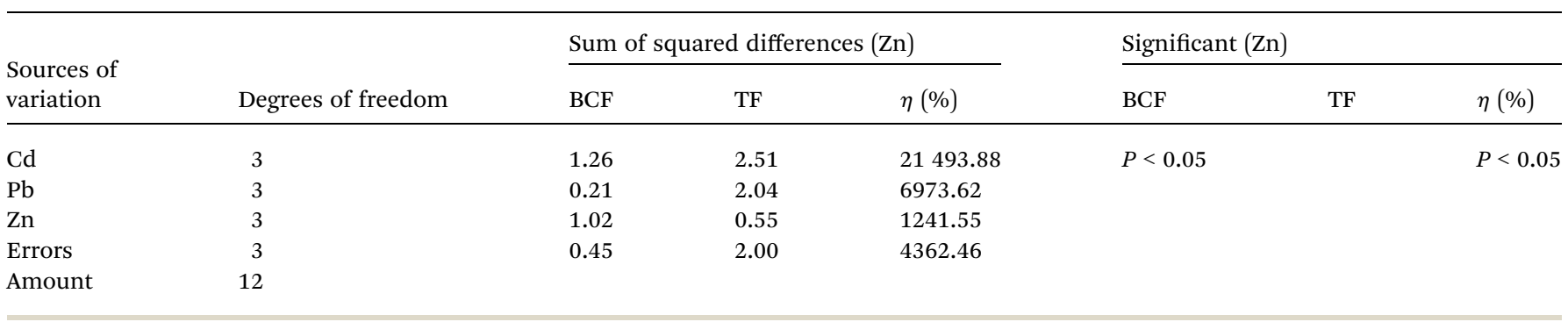

\section{Discussion}

\subsection{Analysis of the effect of combined action}

3.1.1 Effect of the combined action of $\mathrm{Cd}, \mathrm{Pb}$ and $\mathrm{Zn}$ on their accumulation in ryegrass. As can be seen in Table 3, compared with the case of the control group (T1), the accumulation of various elements in ryegrass was significantly increased except for a few cases. The content of $\mathrm{Cd}$ and $\mathrm{Pb}$ in roots significantly increased, and their maximum content was about 23.45 and 16.67 times that in the control group, respectively. The content of $\mathrm{Zn}$ in the stem and leaf significantly increased, and the maximum content of $\mathrm{Zn}$ was about 15.33

Table 7 Accumulation of heavy metal elements in ryegrass based on the interactive experiment

\begin{tabular}{|c|c|c|c|c|c|c|c|c|c|}
\hline \multirow[b]{2}{*}{ Treatments } & \multicolumn{3}{|c|}{$\begin{array}{l}\text { Heavy metal } \\
\text { elements }\end{array}$} & \multicolumn{3}{|c|}{ Heavy metal content in root/mg kg $\mathrm{kg}^{-1}$} & \multicolumn{3}{|c|}{ Heavy metal content in stem and leaf $/ \mathrm{mg} \mathrm{kg}^{-1}$} \\
\hline & $\mathrm{Cd}$ & $\mathrm{Pb}$ & $\mathrm{Zn}$ & $\mathrm{Cd}$ & $\mathrm{Pb}$ & $\mathrm{Zn}$ & $\mathrm{Cd}$ & $\mathrm{Pb}$ & $\mathrm{Zn}$ \\
\hline S1 & 1 & 1 & 1 & $5.56 f \pm 0.23$ & $30.63 f \pm 0.03$ & $35.20 \mathrm{~h} \pm 0.76$ & $7.42 \mathrm{a} \pm 0.19$ & $27.50 \mathrm{~b} \pm 0.80$ & $58.76 b \pm 1.26$ \\
\hline $\mathrm{S} 2$ & 1 & 2 & 1 & $4.23 g \pm 0.10$ & $39.64 d \pm 0.59$ & $94.47 b \pm 1.00$ & $2.78 \mathrm{~d} \pm 0.00$ & $14.30 \mathrm{e} \pm 0.17$ & $45.29 \mathrm{e} \pm 0.51$ \\
\hline S3 & 1 & 1 & 2 & $1.85 \mathrm{~h} \pm 0.01$ & $33.99 \mathrm{e} \pm 0.48$ & $38.78 \mathrm{~g} \pm 0.47$ & $1.14 \mathrm{e} \pm 0.02$ & $9.54 \mathrm{f} \pm 0.12$ & $31.68 \mathrm{~h} \pm 0.33$ \\
\hline $\mathrm{S} 4$ & 1 & 2 & 2 & $12.55 c \pm 0.26$ & $31.54 \mathrm{f} \pm 0.72$ & $81.77 \mathrm{c} \pm 1.05$ & $1.19 \mathrm{e} \pm 0.01$ & $27.87 b \pm 0.47$ & $37.99 f \pm 0.38$ \\
\hline S5 & 2 & 1 & 1 & $15.11 b \pm 0.10$ & $43.62 c \pm 0.29$ & $73.00 \mathrm{e} \pm 0.77$ & $2.73 d \pm 0.03$ & $10.20 f \pm 0.07$ & $35.58 \mathrm{~g} \pm 0.63$ \\
\hline S6 & 2 & 2 & 1 & $10.00 \mathrm{~d} \pm 0.24$ & $54.34 \mathrm{a} \pm 0.64$ & $76.42 \mathrm{~d} \pm 0.78$ & $5.16 \mathrm{~b} \pm 0.02$ & $15.02 d \pm 0.16$ & $55.63 c \pm 1.63$ \\
\hline S7 & 2 & 1 & 2 & $9.09 \mathrm{e} \pm 0.09$ & $10.31 \mathrm{~g} \pm 0.15$ & $65.64 f \pm 0.68$ & $5.03 b \pm 0.10$ & $17.76 c \pm 0.53$ & $68.01 \mathrm{a} \pm 0.96$ \\
\hline S8 & 2 & 2 & 2 & $33.10 \mathrm{a} \pm 0.56$ & $50.53 b \pm 0.78$ & $105.57 \mathrm{a} \pm 1.17$ & $4.86 c \pm 0.02$ & $31.79 a \pm 0.20$ & $51.04 \mathrm{~d} \pm 0.22$ \\
\hline
\end{tabular}


times that in the control group. This is because the addition of exogenous heavy metals leads to an increase in the total amount of heavy metals in soil; this eventually leads to an increase in the accumulation of heavy metals in plants.

3.1.2 Effect of the combined action of $\mathrm{Cd}, \mathrm{Pb}$ and $\mathrm{Zn}$ on the BCF, TF and EF of ryegrass. The effects of the combined action of $\mathrm{Cd}, \mathrm{Pb}$ and $\mathrm{Zn}$ on the BCF, TF and EF of ryegrass are shown in Fig. 1. As shown in Fig. 1(a), compared with the case of the control (T1), the BCF increased significantly with an increase in element concentration. Although the concentrations of individual elements fluctuated, the overall concentration of heavy metals increased; the order of the growth degree was $\mathrm{Cd}>\mathrm{Pb}>$ $\mathrm{Zn}$; this indicates that the roots of ryegrass have a strong enrichment ability for the heavy metal Cd.

The overall TF of ryegrass increased with an increase in heavy metal concentration. Compared to the case of the control (T1), the order of the growth degree of the three heavy metal ions was $\mathrm{Zn}>\mathrm{Pb}>\mathrm{Cd}$ (Fig. 1(b)). The results show that among the exogenous heavy metals, $\mathrm{Zn}$ is more easily transferred to the ground of ryegrass and best absorbed by the stems and leaves of ryegrass.

As shown in Fig. 1(c), with an increase in heavy metal concentration, the EF of ryegrass towards three heavy metal ions increased as compared to that in the case of the control (T1), and the degree of growth was $\mathrm{Cd}>\mathrm{Zn}>\mathrm{Pb}$. The results showed that among the three heavy metal ions, the efficiency of extracting Cd from ryegrass was highest.

The results of the variance analysis of the orthogonal test for $\mathrm{Cd}$ in the combined action are shown in Table 4. At the 95\% confidence interval, Cd presented a significant influence on its own BCF and EF. Zn revealed a significant effect on the Cd EF $(P<$ 0.05 ) and an insignificant effect on the BCF and TF of Cd. Pb did not show a significant effect on the phytoextraction factor of $\mathrm{Cd}$.

The orthogonal experiment for the heavy metal $\mathrm{Pb}$ in the combined action was performed via the variance analysis (Table $5)$. $\mathrm{Pb}$ had a significant impact on its own EF $(P<0.05)$. Moreover, the three factors did not show a significant influence on the $\mathrm{BCF}$ and $\mathrm{TF}$ of $\mathrm{Pb}$. This indicates that the $\mathrm{EF}$ of $\mathrm{Pb}$ is mainly related to its own concentration and not affected by $\mathrm{Zn}$ and $\mathrm{Cd}$.

Similarly, the results of $\mathrm{Zn}$ variance analysis are shown in Table 6. Cd demonstrated a significant effect on the BCF and EF of $\mathrm{Zn}(P<0.05)$, and no significant influence on other factors. This shows that the BCF and EF of $\mathrm{Zn}$ are mainly affected by $\mathrm{Cd}$.

\subsection{Analysis of the effect of interaction}

3.2.1 Effects of the interactions of $\mathrm{Cd}, \mathrm{Pb}$ and $\mathrm{Zn}$ on the accumulation of heavy metals in ryegrass. After interaction, the accumulation of three heavy metals ( $\mathrm{Cd}, \mathrm{Pb}$ and $\mathrm{Zn}$ ) in ryegrass is shown in Table 7. The accumulation of heavy metal ions in ryegrass significantly increased with the exception of a few cases, and the Cd content increased the most in root. However, the content of various metallic elements in the stem and leaf changed slightly. In addition, the concentration of $\mathrm{Zn}$ in ryegrass is significantly higher than that of $\mathrm{Cd}$ and $\mathrm{Pb}$; this indicates that $\mathrm{Zn}$ is a necessary element for the growth of an organism.
3.2.2 Effects of the interactions of $\mathrm{Cd}, \mathrm{Pb}$ and $\mathrm{Zn}$ on the phytoextraction efficiency of ryegrass. The effects of the interactions of $\mathrm{Cd}, \mathrm{Pb}$ and $\mathrm{Zn}$ on the $\mathrm{BCF}$, TF and $\mathrm{EF}$ of ryegrass are shown in Fig. 2. Fig. 2(a) shows that the maximum BCF values of the three heavy metal ions in ryegrass appear in the cases of $\mathrm{S} 2, \mathrm{~S} 3$ and $\mathrm{S} 2$ when compared with the case of the control $\mathrm{S} 1$; the maximum $\mathrm{TF}$ of $\mathrm{Cd}$ and $\mathrm{Pb}$
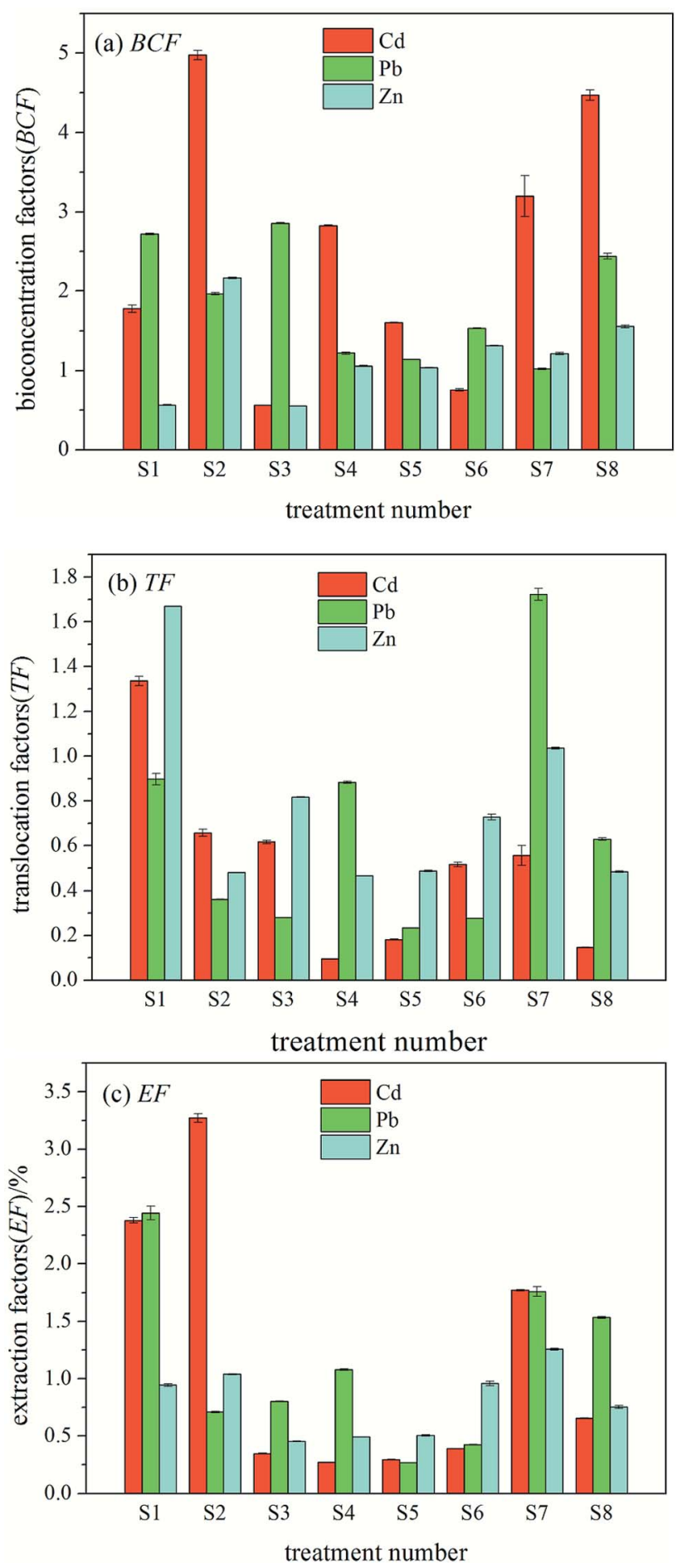

Fig. 2 Effects of the interactions of $\mathrm{Cd}, \mathrm{Pb}$ and $\mathrm{Zn}$ on the BCF, TF, and EF of ryegrass. 
Table 8 Variance analysis of orthogonal experimental of interaction (Cd)

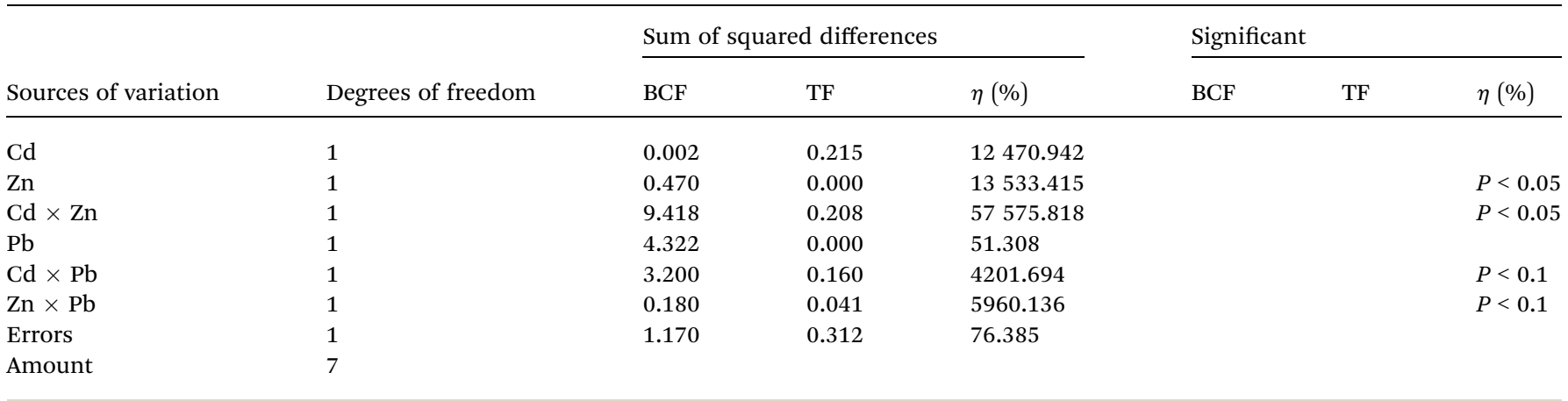

in ryegrass is seen in the case of $\mathrm{S} 1$, and the maximum TF of $\mathrm{Zn}$ is seen in the case of S1 (Fig. 2(b)); as summarized in Fig. 2(c), the maximum $\mathrm{EF}$ of $\mathrm{Cd}$ and $\mathrm{Zn}$ is observed in the cases of S2, S7 and S1.

The variance analysis of the impact of cadmium in the orthogonal experiment of interaction is shown in Table 8. At the $95 \%$ confidence interval, $\mathrm{Zn}$ and $\mathrm{Cd} \times \mathrm{Zn}$ showed significant effects on the EF of $\mathrm{Cd}(P<0.05), \mathrm{Cd} \times \mathrm{Pb}$ and $\mathrm{Zn} \times \mathrm{Pb}$ showed an effect on the EF of Cd $(P<0.1)$, and the sources of variation had no significant effect on other phytoextraction factors. The variance analysis of $\mathrm{Pb}$ and $\mathrm{Zn}$ interaction showed that there was no significant difference between the impacts of each heavy metal ion on the three phytoextraction factors; therefore, the interaction variance analysis of $\mathrm{Pb}$ and $\mathrm{Zn}$ is not listed in Table 8.

\section{Discussion}

\subsection{The main effects of $\mathrm{Cd}, \mathrm{Pb}$ and $\mathrm{Zn}$ on the phytoextraction} efficiency of ryegrass

The main effect analysis selected a series of heavy metal pollution factors (different concentrations of the same contaminant) as the research object in the orthogonal experimental results to make phytoextraction factor change curve with heavy metal concentration as shown in Fig. 3(a)-(c), and the contents of the other two pollution factors were fixed in the selected data. This process can be used to determine the effect of the concentration of a single pollution factor on the restoration of ryegrass and does not require repeated impact experiments of individual factors.

As shown in Fig. 3(a), the BCF and EF increased with an increase in the cadmium concentration and the TF decreased; however, there was no significant difference among the

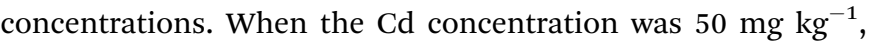
the BCF and EF reached a maximum, which was 9.18 times and 8.21 times that of the control, respectively.

As shown in Fig. 3(b), the Pb phytoextraction factor fluctuated with an increase in lead concentration. The BCF and EF were maximum when the $\mathrm{Pb}$ concentration was $900 \mathrm{mg} \mathrm{kg}^{-1}$, which was 2.33 times and 3.49 times that of the control, respectively. Overall, $\mathrm{Pb}$ had no significant effect on the phytoextraction efficiency.
As shown in Fig. 3(c) the BCF of Zn showed an upward trend except that it decreased when the zinc concentration was $350 \mathrm{mg} \mathrm{kg}{ }^{-1}$. The TF fluctuated with an increase in the $\mathrm{Zn}$ concentration. Moreover, compared with the case of the control, the EF increased with an increase in $\mathrm{Zn}$ concentration, and the maximum value was 1.34 times that of the control, indicating that the change in $\mathrm{Zn}$ concentration presented a certain impact on the EF.

\subsection{Regression analysis of the ryegrass elemental accumulation by combined action}

The results of the multiple regression equation of the effect of cadmium, lead and zinc on the element accumulation in ryegrass are listed in Table 9. It can be seen from the multiple regression equation of $\mathrm{Cd}$ that $\mathrm{Cd}$ shows a positive correlation with its own $\mathrm{BCF}$, whereas $\mathrm{Pb}$ and $\mathrm{Zn}$ present a slight influence on the BCF of Cd. In addition, cadmium, lead and zinc had no effect on the TF of $\mathrm{Cd}$, and cadmium was positively correlated with its own EF. As can be seen from the multiple regression equation of the lead element, lead had a significant influence on its EF, whereas other factors had no significant influence on its phytoextraction factor. According to the multiple regression equation of the zinc element, cadmium had a significant influence on the BCF and $\mathrm{EF}$ of $\mathrm{Zn}$, whereas other heavy metals did not have a significant influence on the phytoextraction factor of $\mathrm{Zn}$. In general, this is consistent with the results of the orthogonal test variance analysis of the combined effects of cadmium, lead and zinc.

The phytoextraction efficiency of ryegrass can be affected by the heavy metal combined pollution. ${ }^{11,21}$ In this study, it was found that under the combined pollution of cadmium, lead and zinc, the enrichment capacity of cadmium in ryegrass roots was higher than that of lead and zinc, and the BCF increased significantly with an increase in cadmium concentration. This may be because cadmium is most active in soil, exists in a water soluble and exchangeable state, and has a strong migration capacity. Moreover, the physical and chemical properties of cadmium and zinc are similar, and the atomic radius is close; furthermore, zinc can reduce the toxicity of cadmium towards ryegrass, increase the enrichment of cadmium in the roots of ryegrass, and promote the absorption and accumulation of 

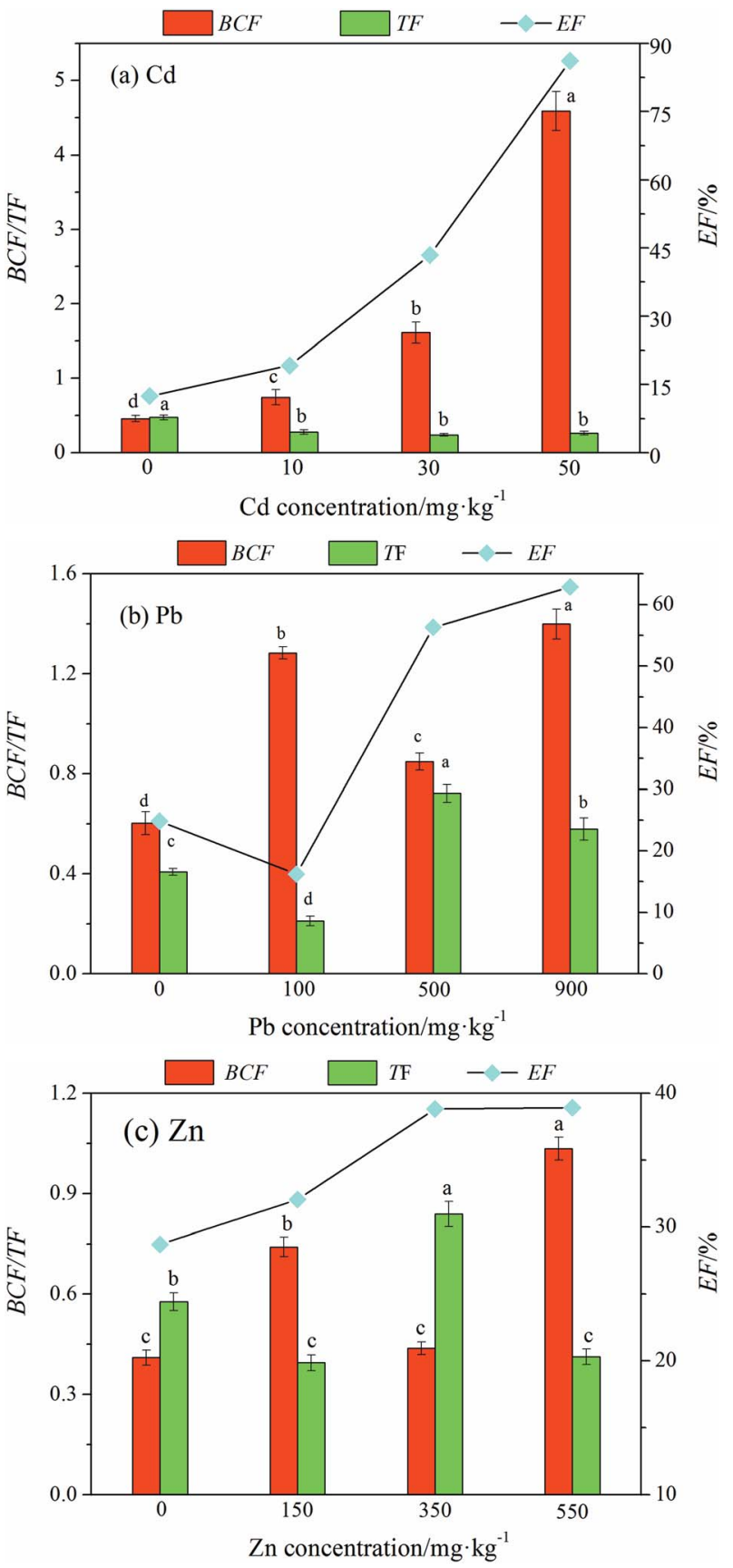

Fig. 3 The three phytoextraction factors varied with the content of heavy metal elements ( $\mathrm{Cd}, \mathrm{Pb}$, and $\mathrm{Zn})$ in soil. cadmium in ryegrass. However, due to the different physical and chemical properties of lead and cadmium, lead is easily absorbed by soil and loses its activity. Therefore, lead presented a slight effect on the accumulation of cadmium and zinc in ryegrass. These findings are consistent with the results reported in the literature..$^{\mathbf{2 0 , 4 0}}$

The interaction of heavy metal elements is related to the absorption, transport, distribution, accumulation and physiological activity of elements in plants. Some elements (such as zinc) can alleviate the toxic effects of heavy metals in plants, thereby increasing the ability of plants to accumulate other heavy metals..$^{3,34,41}$ This study showed that the concentration of zinc in ryegrass was much higher than that of cadmium and lead. It is suggested that ryegrass has the potential to enrich zinc under the interaction effect; this may be because zinc is an essential nutrient element for plant growth, and it is a component or auxiliary of many important enzymes in plants, which can effectively cooperate or antagonize the absorption of other heavy metals and change the absorption intensity of heavy metals in plants.

The variance analysis of interaction orthogonal experiment of $\mathrm{Cd}$ showed that $\mathrm{Zn}$ and $\mathrm{Cd} \times \mathrm{Zn}$ had significant effects on the EF of $\mathrm{Cd}(P<0.05), \mathrm{Cd} \times \mathrm{Pb}$ and $\mathrm{Zn} \times \mathrm{Pb}$ had significant effects on the EF of $\mathrm{Cd}(P<0.1)$, and $\mathrm{Cd}$ and $\mathrm{Pb}$ had no significant effect on the EF of $\mathrm{Cd}$. This may be because there is a competitive relationship between cadmium and zinc as well as a synergistic effect. When the concentrations of $\mathrm{Cd}$ and $\mathrm{Zn}$ are close, the synergy between them becomes the dominant effect, and ryegrass shows certain differences in absorption and enrichment according to their concentration ratio. When the difference between the cadmium and zinc concentrations was greater, the accumulation of cadmium and zinc was inhibited by ryegrass. When the concentrations of $\mathrm{Cd}$ and $\mathrm{Zn}$ were close, a synergistic effect of ryegrass on the enrichment of $\mathrm{Cd}$ and $\mathrm{Zn}$ was observed. This is consistent with the results reported in the literature. ${ }^{30}$ In conclusion, the degree of inhibition or promotion of the restoration efficiency of ryegrass varied with the species, concentration and interaction treatment of heavy metals. This is related to the comprehensive influence of heavy metal-added quality fraction, pollutant factors, biological factors and environmental factors on the environmental effects of the combined pollution.

Table 9 Regression analysis of the ryegrass elemental accumulation by combined action

\begin{tabular}{llll}
\hline Phytoextraction factors & The regression equations & The correlation coefficients \\
\hline \multirow{2}{*}{$\mathrm{Cd}$} & BCF & $Y_{\mathrm{BCF}}=0.118+0.08\left(\mathrm{Cd}^{2+}\right)+0.001\left(\mathrm{~Pb}^{2+}\right)-0.001\left(\mathrm{Zn}^{2+}\right)$ & 0.804 \\
& TF & $Y_{\mathrm{TF}}=0.238-0.003\left(\mathrm{Cd}^{2+}\right)$ & 0.375 \\
$\mathrm{EF}$ & $Y_{\eta}=8.206+1.474\left(\mathrm{Cd}^{2+}\right)+0.027\left(\mathrm{~Pb}^{2+}\right)-0.042\left(\mathrm{Zn}^{2+}\right)$ & 0.704 \\
$\mathrm{~Pb}$ & BCF & $Y_{\mathrm{BCF}}=0.274+0.015\left(\mathrm{Cd}^{2+}\right)+0.001\left(\mathrm{~Pb}^{2+}\right)+0.001\left(\mathrm{Zn}^{2+}\right)$ & 0.633 \\
& TF & $Y_{\mathrm{TF}}=0.365+0.002\left(\mathrm{Cd}^{2+}\right)$ & 0.342 \\
$\mathrm{Zn}$ & EF & $Y_{\eta}=4.653+0.441\left(\mathrm{Cd}^{2+}\right)+0.008\left(\mathrm{~Pb}^{2+}\right)+0.085\left(\mathrm{Zn}^{2+}\right)$ & 0.871 \\
$\mathrm{BCF}$ & $Y_{\mathrm{BCF}}=0.187+0.014\left(\mathrm{Cd}^{2+}\right)$ & 0.747 \\
& TF & $Y_{\mathrm{TF}}=0.601+0.016\left(\mathrm{Cd}^{2+}\right)+0.001\left(\mathrm{~Pb}^{2+}\right)+0.001\left(\mathrm{Zn}^{2+}\right)$ & 0.489 \\
& EF & $Y_{\eta}=12.798+1.872\left(\mathrm{Cd}^{2+}\right)+0.022\left(\mathrm{~Pb}^{2+}\right)+0.023\left(\mathrm{Zn}^{2+}\right)$ & 0.805
\end{tabular}




\section{Conclusions}

(1) Under the complexation of $\mathrm{Cd}, \mathrm{Pb}$ and $\mathrm{Zn}$, the accumulation of elements in ryegrass increased with an increase in exogenous heavy metal concentration; the order of root enrichment was Cd $>\mathrm{Pb}>\mathrm{Zn}$, the order of stem and leaf absorption was $\mathrm{Zn}>\mathrm{Pb}>$ $\mathrm{Cd}$, and the order of total extraction efficiencies of the elements was $\mathrm{Cd}>\mathrm{Zn}>\mathrm{Pb}$. Moreover, ryegrass represented strong enrichment and absorption capacity for cadmium and zinc. When Cd was $50 \mathrm{mg} \mathrm{kg}^{-1}$, the ryegrass roots represented largest adsorption capacity, and the enrichment was 23.45 times that of the control group. When $\mathrm{Zn}$ was $550 \mathrm{mg} \mathrm{kg}{ }^{-1}$, the uptake of ryegrass reached maximum value, which was 15.33 times that of the control group.

(2) Under the combined action of $\mathrm{Cd}, \mathrm{Pb}$ and $\mathrm{Zn}, \mathrm{Zn}$ had a significant effect on the EF of $\mathrm{Cd}$, and $\mathrm{Cd}$ had a significant effect on the BCF and EF of $\mathrm{Zn}$; Zn could reduce the toxicity of Cd towards ryegrass and promote the absorption and accumulation of Cd in ryegrass; the maximum enrichment coefficient and extraction efficiency of ryegrass for Cd were 15.3 and 1.6 times that of the control group, respectively. Cd can activate $\mathrm{Zn}$ in soil and promote the enrichment and extraction of $\mathrm{Zn}$ by ryegrass. The maximum enrichment coefficient of $\mathrm{Zn}$ in ryegrass was 1.54 , and the maximum transfer coefficient was 1.17.

(3) Under the interaction of $\mathrm{Cd}, \mathrm{Pb}$ and $\mathrm{Zn}, \mathrm{Zn}$ and $\mathrm{Cd} \times \mathrm{Zn}$ showed significant effects on the EF of Cd in ryegrass $(P<0.05)$. The maximum extraction efficiency coefficient of ryegrass for $\mathrm{Cd}$ was 1.6. $\mathrm{Cd} \times \mathrm{Pb}$ and $\mathrm{Zn} \times \mathrm{Pb}$ had an effect on the $\mathrm{EF}$ of $\mathrm{Cd}$ in ryegrass $(P<0.1)$. The interaction had no significant effect on the phytoremediation efficiency of $\mathrm{Zn}$ and $\mathrm{Pb}$.

\section{Funding}

This work was supported by the Program of National Natural Science Foundation of China (41771215), the Open Fund of Key Laboratory of Subsurface Hydrology and Ecological Effects in Arid Region (Ministry of Education) (No. 310829151140), and the Open Fund of Key Laboratory of Subsurface Hydrology and Ecological Effects in Arid Region (Ministry of Education) (No. 310829151141).

\section{Conflicts of interest}

There are no conflicts to declare.

\section{References}

1 B. L. Clabeaux, D. A. Navarro, D. S. Aga and M. A. Bisson, Ecotoxicol. Environ. Saf., 2013, 98, 236-243.

2 X. Zhai, Z. Li, B. Huang, N. Luo, M. Huang, Q. Zhang and G. Zeng, Sci. Total Environ., 2018, 635, 92-99.

3 O. V. Singh, S. Labana, G. Pandey, R. Budhiraja and R. K. Jain, Appl. Microbiol. Biotechnol., 2003, 61, 405-412.

4 R. D. Harter and R. Naidu, in Advances in Agronomy, ed. D. L. Sparks, Academic Press, 1995, vol. 55, pp. 219-263.
5 S. Willscher, L. Jablonski, Z. Fona, R. Rahmi and J. Wittig, Hydrometallurgy, 2017, 168, 153-158.

6 Z. J. Xu, C. H. Wu, X. Y. Qiu and H. Zhang, J. Soil Water Conserv., 2007, 1-6.

7 X. Pan, F. C. Shi, L. M. Liu, M. W. Cai and F. C. Liu, J. Bot., 2012, 32, 717-723.

8 N. Sooksawat, M. Meetam, M. Kruatrachue, P. Pokethitiyook and K. Nathalang, J. Environ. Sci., 2013, 25, 596-604.

9 K. Mahdavian, S. M. Ghaderian and M. Torkzadeh-Mahani, J. Soils Sediments, 2015, 1-11.

10 M. Poniedziałek, A. Sekara, E. Jedrszczyk and J. Ciura, Folia Hortic., 2010, 22, 25-31.

11 A. Bernardini, E. Salvatori, V. Guerrini, L. Fusaro, S. Canepari and F. Manes, Int. J. Phytorem., 2016, 18, 16-24.

12 S. Khalid, M. Shahid, N. K. Niazi, B. Murtaza, I. Bibi and C. Dumat, J. Geochem. Explor., 2017, 182, 247-268.

13 X. W. Liu, Y. Li, Z. R. Nan, Z. J. Zhao, H. X. Ding and S. L. Wang, J. Lanzhou Univ., Nat. Sci., 2009, 45, 1-6.

14 J. F. Zhu, M. H. Li, P. J. Xie and Y. L. Qiao, Chin. J. Eco-Agric., 2018, 26, 303-313.

15 X. Yang, Y. Feng, Z. He and P. J. Stoffella, J. Trace Elem. Med. Biol., 2005, 18, 339-353.

16 L. B. Zhou, Q. Wu and G. L. Gao, Appl. Mech. Mater., 2012, 209-211, 1116-1119.

17 F. P. C. Blamey, D. C. Joyce, D. G. Edwards and C. J. Asher, Plant Soil, 1986, 91, 171-180.

18 P. Rojjanateeranaj, C. Sangthong and B. Prapagdee, Chemosphere, 2017, 185, 764-771.

19 G. F. Koopmans, P. F. A. M. Römkens, M. J. Fokkema, J. Song, Y. M. Luo, J. Japenga and F. J. Zhao, Environ. Pollut., 2008, 156, 905-914.

20 Y. Zhang, Z. G. Tian, C. L. Cao, J. C. Liu and J. Q. Kang, J. Agro-Environ. Sci., 2010, 29, 2080-2086.

21 Y. Y. Sun, P. Guan, S. He and J. M. Shi, Pratacult. Sci., 2016, 33, 1589-1597.

22 M. J. He, H. R. Shen, Z. T. Li, L. Wang, F. Wang, K. L. Zhao, X. M. Liu, O. Wendroth and J. M. Xu, Environ. Pollut., 2019, 244, 431-439.

23 S. Y. Lin and Y. B. Feng, Environ. Eng., 2017, 35, 168-173.

24 N. Bolan, A. Kunhikrishna, R. Thangarajan, J. Kumpiene, J. Park, T. Makino, M. B. Kirkham and K. Scheckel, J. Hazard. Mater., 2014, 266, 141-166.

25 H. Xie, L. Zhu and J. Wang, Environ. Sci. Pollut. Res., 2018, 111.

26 G. Vigliotta, S. Matrella, A. Cicatelli, F. Guarino and S. Castiglione, J. Environ. Manage., 2016, 179, 93-102.

27 R. J. Reid, J. D. Brookes, M. A. Tester and F. A. Smith, Planta, 1996, 198, 39-45.

28 P. Feng, L. Sun, X. H. Shen, C. Jiang, R. L. Li, Z. J. Li, H. Y. Zheng, H. Zhang, W. Gou, X. D. Han and Y. N. Hong, Acta Prataculturae Sinica, 2016, 25, 153-162.

29 A. K. Salama, K. A. Osman and A. R. Gouda, Int. J. Phytorem., 2016, 18, 364-367.

30 W. H. Xu, Z. T. Xiong, H. X. Wang, Y. R. Li, J. Z. Liu and W. Y. Li, J. Soil Water Conserv., 2005, 32-35.

31 J. Zhang, W. K. Wang, Y. N. Geng, X. Y. Ren, Z. F. Wang and S. M. Cao, J. Agro-Environ. Sci., 2018, 37, 1117-1124. 
32 A. Mahar, P. Wang, A. Ali, M. K. Awasthi, A. H. Lahori, Q. Wang, R. Li and Z. Zhang, Ecotoxicol. Environ. Saf., 2016, 126, 111-121.

33 C. B. Tabelin, T. Igarashi, M. Villacorte-Tabelin, I. Park, E. M. Opiso, M. Ito and N. Hiroyoshi, Sci. Total Environ., 2018, 645, 1522-1553.

34 J. Guo, R. Feng, Y. Ding and R. Wang, J. Environ. Manage., 2014, 141, 1-8.

35 Y. Lee, J. J. Filliben, R. J. Micheals and P. Jonathon Phillips, Comput. Vis. Image Underst., 2013, 117, 532-550.
36 J. Tang, G. Gong, H. Su, F. Wu and C. Herman, Appl. Energy, 2016, 169, 696-708.

37 D. S. Sui and Z. S. Cui, Appl. Energy, 2009, 22, 13-21.

38 J. Yoon, X. Cao, Q. Zhou and L. Q. Ma, Sci. Total Environ., 2006, 368, 456-464.

39 A. S. Reza Hesami and S. M. Ghaderian, Environ. Sci. Pollut. Res., 2018, 25, 1-14.

40 Z. Yang, W. Wang, B. W. Li, Y. J. Guo and H. X. Wang, J. Soil Water Conserv., 2008, 83-87.

41 M. I. Dar, I. D. Green, M. I. Naikoo, F. A. Khan, A. A. Ansari and M. I. Lone, Sci. Total Environ., 2017, 584-585, 1221-1229. 